あるいは系統は数が限られているから，之と平行して大 体皆の実験に共通な最大公約数的な目標を定めて, 近親 交配をつづけて遺伝子の固定をはかる。その場合どうい 5型の遺伝子組成に固定するかはわからないのであるか ら系統が出来上つても，その系統の特性がはつきりしな い。そこで適宜に種々の適応試験を行つてその系統に特 性の意味ずけをして行く。この考え方を理解して載くた めに，す51度 BHC の抵抗性をしらべた第3表を見て もらいたい。この実験に用いた禿統は，体重に対して特 性を持たせるように育成した系統であるが，系統によつ て死亡率に非常な差があつて，事実上 BHC に対して反 応の異る系統はつくられていたわけである。このように して多くの固定した系統が用意されていれば，新しい研 究課題が生じてる，適灾試䟻によつて目的にそつた采統 がすぐに見出される䈍で，その場になつて育成を急がな いでもよいようになる。

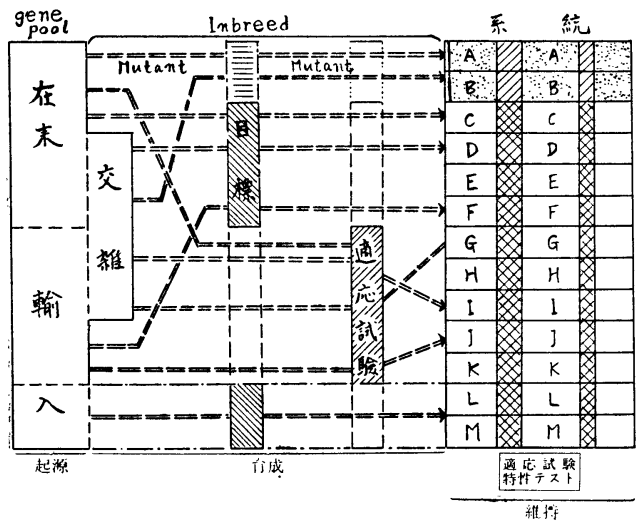

第 7 図 系統の育成と維持
以上の考えを模式的に示したものが第7図である。系 統育成の起源はなるべく多くの種類の遗伝子がある方が よいから, 在来のもの, 輸入のもの, 及び之等の交雑と いらょうにする。その中に生じた遺伝子記号をるつて示 せるような Mutantは，そのまま固定させて系統とし て保存する。文始めから研究上必要な目標のある場合 は，その目標に向つて系統を育成する。更に 1 方では目 標は明膫でないまを近親交配をつづけ，適応試験によつ て意味ずけられる系統育成も存在する。又外国から特性 のわかつた系統も輸入される。その上らにして系統を育 成し維持しておくが, その特性とよぶものが複雑な生理 現象をさしていうのであるから, 遺伝子の突然变巽によ つて生理機構のかわる場合もあるか子しれないし, 系統 育成の過程で常にテストして選抜していたものを，その ままテストせず維持することは，今までと異る「正常 の状態」で選抜していることになるから，世代数をませ ば晎る方向に变化して行くことも考兄られる。従つて維 持するについても, 時々その特性を確認する必要がある し, 又新しい研究課題が生じた場合には適応試験をして その研究に適したものを探し出す必要もある。

\section{参考書 目}

GRÜNEBERG, H. (1952): The Genetics of the Mouse, Martinus Nijhoff, The Hague, Netherlands.

Lerner, I. M. (1950): Population Genetics and Animal Improvement, Cambridge at the Univ. Press, Great Britain.

Lush, J. L. (1919): Animal Breeding Plans, The Iowa State College Press, Ames, Iowa, U.S.A.

$$
\begin{gathered}
\text { 日本モンキーセンターの設立 } \\
\text { —サルと医学研究— }
\end{gathered}
$$

日本モンキーセンター常務理事 安 東 洪 次

本誌第 1 巻 6 号のサル特輯号の中で，われわれは二小 ンザルを医学研究に使うための遠大な計画と，それまで の成果とを発表したが，あれから4年経つた今日，その 夢が日本モンキーセンターといら形で愛知県犬山市に凝 結した。

志賀重昂の命名になる日本ラインで有名な犬山市の桃 太郎公園の中に， 50 坪程のモダンな日本モンキーセン ターの事務所ができ上つて, 10 月 28 日にその開所式 が盛大に挙行された。その目的はニホンザルの社会生態 学的研究を基盤として, 各地の野生ニホンザルの保護繁 殖を実施指導すると共に, 繁殖のために群の構版を規正 する際に間引いた雄ザルや，猿害地で捕檴したサルを研
究に供給するにあるが, 将来は研究所を附設してサルの 動物学的, 医学的研究を行い, サル動物園を作つて世界 のむらゆる種類のサルを集める計画である。

これらの仕事は名古屋鉄道で企画中の, 犬山公園の自 然公園化計画と結付いて行われるるので, 名古屋鉄道出 資の下に財国法人日本モンキーセンターが設立されたの もそのためである。日本公園協会理事長田村剛博士が理 事長となり，名鉄副社長土川元夫巨，実験動物研究会側 として安東及び田嶋嘉雄氏, 霊長類研究グループとして 宮地伝三郎, 今西錦司の両氏, 名古屋大学医学部長戸刚 近太郎氏らが理事として会の運営に当る次第である。

現在 (11 月 30 日) 既に 20 数個の檻を容れたサル舎 
と，金網作りのドーム（第一次訓練用）及び 300 坪程の 第二次訓練放飼場とができ上り，サル舎には 20 数頭, ドームに 10 数頭, 訓練放飼場に 30 余頭のサルが収容 されて居て, 研究用の需要に備えていると同時に, 放飼 の時期 ( 3 月頃の見込) を待つている。他方過去数年に 亘つて霊長類研究グループの諸君が研究開拓した保護繁 地は既に 10 力所に及び，それぞれ健全な繁殖を遂げて いると同時に, 社会生態学的研究も進んでいろいろ新し いデータが集積されている。

高崎山のサルは現在既に 440 頭に及び，今年 31 年の 出座怯 83 頭で今後益: 增殖の傾向にあるが, 雄の過剩 が群の不安定を招いているので雄の間引きが必要となつ てきている。老年期に入つていた宮崎県幸島の群も，や らやく成熟期に入つた牝が増加してきて 31 年の出産は 7 頭になつたし, 香川県小豆島, 大阪府箕面, 広島県帝 釈峡, 和歌山県椿, 京都府嵐山, 岡山県高梁などの群に 閭する調查もだんだん精備してきた。他方鹿児島県屋久 島や，小豆島北部の猿害地での捕獲も順調に進んで，実 験用サル供給事業の方も着々進捗している。

フランスの CLAUD BERNARD の書いた実験医学序 説は動物実験による医学研究の道を示した優れた最初の 本と考えられるが，近親交配によつて作つた，いろいろ の生理的特徽を持つた近交系動物を実験医学溥入した のは米国の LITTLE の功績ということができる。哺乳 動物として人と共通な生理作用, 例えばビタミン, ホル モン，栄養などの問題を分析的に 研究するにはこの近 交系動物は医学に対して測り知れない寄与をなしている が，人とウサギ，モルモット，マウスなぞとの間には越
え難い差巽がある。この差異を縮めるには人に最も近い サルが撰ばれねばならない。斯くして近代医学の進歩は 実験動物としてのサルに対する強い要求となつて現われ てきている。米国では年間 10〜20 万頭のサルがインド から輸入されて医学研究に使われているが，国内繁殖を 行う場合の高価 (150 弗程度) なサルでむ数干乃至数万 頭が要望される見込であるという。以て米国に於けるサ ルの要求の程度を知ることができる。

11 月 28,29 の両日, 日本モンキーセンターで, 第 一回の研究会が開かれて医学, 獣医学及び動物学の研究 者 20 数名が参集して, いろいろの討議が行われた。そ の中で慶応内科の長谷川氏は脳循環に関するいろいろの 問題を研究しているが，犬による過去の研究の完全な失 敗の後, サルを使うようになつて始めて研究が軌道に乗 りだしたことを報告された。脳循環系や脳組織の異なる 犬での研究が人に当てはまらぬことは当然のことである が，いろいろの方面で同じような失敗が絽返えされてい る現状を見るにつけても，一日も早く日本の医学界に廉 価なサルを充分に供給することが，本センターの大きな 任務であると考兄る。なお名大学長勝沼精蔵博士は本七 ンターの開所式の際の祝辞の中で, 米国でのサルによる 実験の現状と実䀎動物としてのサルの重要性について述 べられたが，その中で血液学研究におけるサルの重要性 を強調された。

このような医学界の要望に答えることのできるのも， そう遠い将来ではないと確信しているが，各方面から の，殊に医学界からの激沩と支援とを希望してやまない 次第である。

\section{日本モンキーセンター}

\section{第 1 回研究者総会記 事}

11 月 29,30 の両日に亘つて第1回の研究者総会が, 新しく出来上つたセンターの会議室で開かれた。医学, 獣医学, 動物学など各方面の研究者 20 数名出席の下に, 生態部門と医学部門とに分れて報告討議が行われた。精 しい内容は原著として発表される预定であるが，ここに それらの概略に就て述べる。

医学部門では安東が医学研究に括けるサルの意義につ いて述べた後, 鈴木(伝研)はセンターから供給したサル の用途に就て, 長谷川(慶応内科)は脳循環に関する自己 の研究に就て, 奥野(阪大微研)はマラリアと麻珍研究に 関する自己の経験に就て，田中(予研)は固形飼料と飼育 管理に就て, 今泉(予研)は自然感染に就て, 最後に石井 (慈恵耳鼻科)は鼻骨の進化論的研究について講演を行つ た。
CLAUD BERNARD によつて拓かれた実験医学は, LITTLE による近交系実験動物の導入によつて著しい 進歩を遂げたが，近交系動物は哺乳動物として人と共通 の生理作用を持つているため, その分析的研究を行5上 で欠くべからざるものとなつているものであつて, 人と これらの実験動物との間にある厳然とした差異を如何と もすることはできない。この羑異をできるだけ縮めるに は人類に最も近いサルが用いられねばならない。このこ とが近代医学のサルに対する要望を高めた所以である。 (安東)。

今日までにセンターから供給したサルは 105 頭である が, その中，医学研究に用いられたもの 83 頭，動物学， 心理学方面に用いられたもの 22 頭である。医学研究と してはウイルス 48 頭, 結核 2 頭, 病变米 12 頭, 抗生 